\title{
Evaluation of different variables of agression levels of physical education and sports school and educational faculty students
}

\author{
Ercan POLAT, Serkan HAZAR, Zekihan HAZAR
}

Nŏide Ömer Halisdemir Universty Physical Education and Sport School, Niğde, Turkey.

Address correspondence to Z. Hazar, e-mail: zekihanhazar84mail.com

\begin{abstract}
The aim of this study is to examine the aggressiveness of the students who are studying at the Faculty of Education and the School of Physical Education and Sports. In this research, which adopted the quantitative research model, the relational search pattern was used. In this context, a total of 213 people, 104 female and 109 male, participated in the survey. The "Buss Perry Aggression Scale" was adapted by Can (5) to determine the level of aggression of participants in the study. SPSS 20 program was used in the analysis of the data. In the analysis of the data, $\mathrm{T}$ test was used to examine the difference between two independent variables and aggression attitudes. Pearson corelation was used to test the relationship between variables. According to the findings, it was determined that there is a significant relationship between the aggressiveness levels of the individuals and gender and type of sport that they made. It was seen that there was no meaningful relationship between age, the part of education, whether or not doing sports, the frequency of doing sports and the duration of sports. It has been determined that male individuals are higher in physical aggression subscale than female individuals. When the relationship between the department where they are educated and the aggressiveness is examined, it is determined that the students who are studying at the Physical Education and Sports are higher than the students who are educated at the 492 Faculty of Education in the physical aggression sub-dimension. It is determined that the students who play sports are higher than the students who play sports in all sub dimensions of sports students. As a result; the fact that aggression behaviors differ according to various variables, but the fact that there is not a statistically significant difference between participants who do sports and those who do not, is quite striking in contradiction with various theories in the field.
\end{abstract}

Keywords: Agression, sport, education, physical education

\section{INTRODUCTION}

Aggression is an important problem in every aspect of life. It has become possible to face violence in education, in family life, in school life, wherever there are human relations. Although aggression is an important problem of today's society, it shows itself very clearly in the sport.

Aggression is accepted as a common instinct in all living things. Nutrition, protection, sexuality, fear, anxiety, and especially anger, such as triggering situations triggered by a living thing to another physical, verbal or psychological damage, such as the behavior is expressed $(17,6,5,2,3,9,8$, 21).

When the literature is examined; there are many theories trying to explain the behavior of aggression. Instinct Theory, Biological Theory, Blocking Aggression Theory, Tip Excitation Theory, Social Cognitive Learning Theory $(11,13,23,16,1,9)$.
In the literature, it is seen that aggressive behavior occurs in different forms and a classification is made in this respect. Aggression, if necessary, with sporty examples; Goal-Oriented Aggression; kick-and-beat behaviors that aim to score in the hands of an opponent who wants to score in the basketball or to outmaneuver his opponent in karate are the behaviors that are performed only to reach a goal without any intention of hostility. This type of aggressive behavior is often seen in order to obtain a better degree, to defeat an opponent, to break a record, to win a medal, or to increase the risk of a high reward or loss of a premium (7). Instrumental Aggression; the aim in instrumental aggression is not to cause pain and harm to the other person, but to use aggression as a tool for the realization of a purpose. In other words, instrumental aggression is an end result. For example, in handball, the pivot player is instrumental aggression when he hits the defensive 
player to give him a comfortable throwThis is the kind of aggression that a defender wants to push the attacker without having to make the ball more comfortable during a corner kick (23). Aggression Under Command; athletes are guided to play harder by their coaches in the competitions that they or their team have to win in absolute situations, when the work and social environment perceive success as mere win. Athletes under the order of the coach can perform unlimited aggressive behaviors in order to win the desired. (7). Hostility Aggression; many of the social psychologists argue that there is an aggression whose primary purpose is to harm someone. They often call such aggression an aggression that includes hostility, and they think this aggression as emotional or anger aggression. The attacker sends unpleasant stimuli to others and tries to harm them (21). Sports athletes in a competition using body language or verbally disturbing behavior.

Sport; it is a challenge that compels the game to compete, reward the winners, and require constant effort because of the high level of play, combat and heavy muscle work. The aim in sport; pleasure has been to make money and make a living now, as it is to evaluate leisure and admit supremacy. Man is an asset with the motivation to succeed. To dominate the world, the environment, the world is a motive that is inherent in man. If this motive is not channeled in the right direction, violence and aggression occur. (19).

During sport aggression, sporting competition or competition, one or more of the elements (athletes, coaches, viewers) involved in the event are affected by psychological, biological or social factors and are excluded from the sports-specific rules of the competition, verbal or physical actions (7). The purpose of sporting competitions is to compete and win gentlemen. athletes, managers, supporters, clubs and even societies that bring closer to each other, fuser and friendship should be strengthening ties (26).

Some Violent Incidents in Sports Areas in the World; In England in 1964 between Bolton and Stoke in the UK Cup semifinal match 33 people were crushed to death. (22). In May 1964 in Lima (Peru), during the match against the Tokyo Olympics qualifier group Peru-Argentina, the referee canceled the home team's goals. In July 1994, Andres Eskober, the defender of the Colombian National Team, who said goodbye to the World Cup in the first round, was killed by fanatic fans in the country (10).
Important Events Occured violence in sport arenas in Turkey; In the 1967-1968 Second Professional League, 38 people lost their lives in the match played between Kayseri and Sivasspor (22). In October 1993, as a result of ground-fighting, Selçuk Soner was killed by a fanatic rally between Kocaelispor and the fans of Kocaelispor (25).

When these evaluations are taken into consideration, it is aimed to investigate the relationship between the underlying causes of the violence in sports and the development of solutions to solve this problem.

\section{METHOD}

In this section, the universe and the sample of the research, the data collection tools used in the research, the data to be followed in the data collection and the statistical methods used in the analysis of the data are emphasized.

\section{Research Model}

In this study, a relational survey model was used to describe the situation. Screening models are scanning arrangements on a whole group or sample taken from the universe or a whole to be able to make a general judgment about the universe in a universe consisting of a large number of elements. Screening models are research approaches that aim to describe a situation that exists in the past or the present. The main thing in this model is to observe the existing situation without changing (14).

\section{Research Universe and Sample}

The universe of research consists of the students of Niğde Ömer Halisdemir University Physical Education and Sports School and the Faculty of Education. The sample group consisted of a total of 213 participants, 109 male and 104 female, who were selected by random selection method.

\section{Data Collection Tools}

In the study, Ag Aggression Questionnaire Scale which was developed by Can (5) and adapted to Turkish by Buss and Perry (5) was used as data collection tools. A personal information form was also used.

\section{Aggression Questionnaire}

Aggression Questionnaire was developed to measure aggression by Buss and Perry. The scale was developed in 5-point Likert-type $(5,18)$.

Statistical Analysis of the Data 
The SPSS (Statistical Package for Social Sciences) for Windows 24.0 program was used for statistical analysis. Pearson Correlation Analysis, TTest, One-Way Analysis of Variance and Tukey Test were used as hypothesis tests. The results were evaluated in the $95 \%$ confidence interval and the significance was evaluated as $\mathrm{p}<0.05$.

\section{FINDING}

Table 1. Comparison of aggression levels of male and female students. t-test

\begin{tabular}{|c|c|c|c|c|c|c|c|}
\hline Gender & & $\mathrm{n}$ & $x$ & Ss & $\mathrm{df}$ & $\mathrm{t}$ & $\mathrm{p}$ \\
\hline \multirow[t]{2}{*}{ Physical Aggression } & Female & 104 & 2.31 & 0.92 & \multirow{2}{*}{211} & \multirow{2}{*}{-2.68} & \multirow{2}{*}{0.01} \\
\hline & Male & 109 & 2.65 & 0.89 & & & \\
\hline \multirow[t]{2}{*}{ Verbal Aggression } & Female & 104 & 2.76 & 0.77 & \multirow{2}{*}{211} & \multirow{2}{*}{-1.80} & \multirow{2}{*}{0.07} \\
\hline & Male & 109 & 2.96 & 0.82 & & & \\
\hline \multirow{2}{*}{$\begin{array}{l}\text { Indirect } \\
\text { Aggression }\end{array}$} & Female & 104 & 2.50 & 0.78 & \multirow{2}{*}{211} & \multirow{2}{*}{-0.76} & \multirow{2}{*}{0.44} \\
\hline & Male & 109 & 2.59 & 0.82 & & & \\
\hline \multirow[b]{2}{*}{ Anger } & Female & 104 & 2.73 & 0.69 & \multirow{2}{*}{211} & \multirow{2}{*}{-1.29} & \multirow{2}{*}{0.19} \\
\hline & Male & 109 & 2.85 & 0.67 & & & \\
\hline \multirow{2}{*}{ Hostility } & Female & 104 & 2.79 & 0.80 & \multirow{2}{*}{211} & \multirow{2}{*}{-0.56} & \multirow{2}{*}{0.57} \\
\hline & Male & 109 & 2.85 & 0.72 & & & \\
\hline
\end{tabular}

In order to examine the difference between the gender and the Aggression Scale sub-dimensions, an independent $t$-test was used to examine the difference between the two average students. According to this; While there was no significant difference in verbal aggression, indirect aggression, anger and hostility sub-dimensions, there was a significant difference between sexes in the sub- dimension of physical aggression $(t=-2.68 ; p=0.01)$. The arithmetic averages between sub-dimensions were examined to determine which group was in favor of the significant difference. When the values were examined, it was seen that physical aggression of males was higher than females in the subdimension of physical aggression (female $X=2.31$; male $X=2.65$ ).

Table 2. Student's t test results according to the department variable.

\begin{tabular}{|c|c|c|c|c|c|c|c|}
\hline Department & & $\mathrm{n}$ & $X$ & Sd & $\mathrm{df}$ & $\mathrm{t}$ & $\mathrm{p}$ \\
\hline \multirow{2}{*}{ Physical Aggression } & Physical Education & 109 & 2.68 & 0.85 & \multirow{2}{*}{211} & \multirow{2}{*}{3.27} & \multirow{2}{*}{0.00} \\
\hline & Education Faculty & 104 & 2.28 & 0.94 & & & \\
\hline \multirow{2}{*}{ Verbal Aggression } & Physical Education & 109 & 2.91 & 0.79 & \multirow{2}{*}{211} & \multirow{2}{*}{0.84} & \multirow{2}{*}{0.40} \\
\hline & Education Faculty & 104 & 2.81 & 0.81 & & & \\
\hline \multirow{2}{*}{ Indirect Aggression } & Physical Education & 109 & 2.61 & 0.79 & \multirow{2}{*}{211} & \multirow{2}{*}{1.13} & \multirow{2}{*}{0.25} \\
\hline & Education Faculty & 104 & 2.48 & 0.80 & & & \\
\hline \multirow{2}{*}{ Anger } & Physical Education & 109 & 2.81 & 0.66 & \multirow{2}{*}{211} & \multirow{2}{*}{0.41} & \multirow{2}{*}{0.68} \\
\hline & Education Faculty & 104 & 2.77 & 0.70 & & & \\
\hline \multirow{2}{*}{ Hostility } & Physical Education & 109 & 2.83 & 0.70 & \multirow{2}{*}{211} & \multirow{2}{*}{0.23} & \multirow{2}{*}{0.81} \\
\hline & Education Faculty & 104 & 2.81 & 0.82 & & & \\
\hline
\end{tabular}

In order to examine the difference between the sub-dimensions of the Faculties and Aggression in the sub-dimension of physical aggression (besyoült $=2.68$; educational $\breve{g}=2.28$ ). Scale sub-dimensions of the students who participated in the study. an independent t-test was applied. According to this; While there was no significant difference between verbal aggression. indirect aggression. anger and hostility subdimensions. there was a significant difference between faculties in physical aggression $(t=3.27 ; p=$ $0.00)$. The arithmetic averages between subdimensions were examined to determine which group was in favor of the significant difference. When the values were examined, it was determined that the physical aggression of Physical Education and Sport was higher than the Faculty of Education 
Table 3. The t-test results of the students about the sport variable.

\begin{tabular}{|c|c|c|c|c|c|c|c|}
\hline Sport status & & $\mathrm{n}$ & $x$ & $\mathrm{Sd}$ & $\mathrm{df}$ & $t$ & $p$ \\
\hline \multirow{2}{*}{ Physical Aggression } & Yes & 141 & 2.56 & 0.92 & \multirow{2}{*}{211} & \multirow{2}{*}{1.67} & \multirow{2}{*}{0.09} \\
\hline & No & 72 & 2.34 & 0.91 & & & \\
\hline \multirow{2}{*}{ Verbal Aggression } & Yes & 141 & 2.86 & 0.80 & \multirow{2}{*}{211} & \multirow{2}{*}{0.08} & \multirow{2}{*}{0.93} \\
\hline & No & 72 & 2.85 & 0.80 & & & \\
\hline \multirow{2}{*}{ Indirect Aggression } & Yes & 141 & 2.53 & 0.80 & \multirow{2}{*}{211} & \multirow{2}{*}{-0.46} & \multirow{2}{*}{0.64} \\
\hline & No & 72 & 2.58 & 0.80 & & & \\
\hline \multirow{2}{*}{ Anger } & Yes & 141 & 2.75 & 0.67 & \multirow{2}{*}{211} & \multirow{2}{*}{-1.22} & \multirow{2}{*}{0.22} \\
\hline & No & 72 & 2.87 & 0.70 & & & \\
\hline \multirow{2}{*}{ Hostility } & Yes & 141 & 2.79 & 0.75 & \multirow{2}{*}{211} & \multirow{2}{*}{-0.73} & \multirow{2}{*}{0.46} \\
\hline & No & 72 & 2.87 & 0.78 & & & \\
\hline
\end{tabular}

In order to examine the difference between the difference between the sporting situation and the aggressiveness scale sub-dimensions. sporting situation of the students participating in the study and the sub-dimensions of the Aggression Scale, an independent t-test was applied. According to this; It was found that there was no significant

Table 4. Comparison of the level of aggression among students according to the type of sport. t-test

\begin{tabular}{|c|c|c|c|c|c|c|c|}
\hline \multicolumn{2}{|c|}{ Type of sport } & $\mathrm{n}$ & $x$ & $\mathrm{Sd}$ & $\mathrm{df}$ & $\mathrm{t}$ & $\mathrm{p}$ \\
\hline Physical & İndividual & 107 & 2.48 & 0.94 & \multirow{2}{*}{139} & \multirow{2}{*}{-1.93} & \multirow{2}{*}{0.05} \\
\hline Aggression & Team & 34 & 2.83 & 0.82 & & & \\
\hline \multirow{2}{*}{ Verbal Aggression } & İndividual & 107 & 2.79 & 0.86 & \multirow{2}{*}{139} & \multirow{2}{*}{-1.98} & \multirow{2}{*}{0.04} \\
\hline & Team & 34 & 3.01 & 0.55 & & & \\
\hline \multirow{2}{*}{ Indirect Aggression } & İndividual & 107 & 2.45 & 0.79 & \multirow{2}{*}{139} & \multirow{2}{*}{-2.15} & \multirow{2}{*}{0.03} \\
\hline & Team & 34 & 2.78 & 0.77 & & & \\
\hline \multirow{2}{*}{ Anger } & Individual & 107 & 2.68 & 0.70 & \multirow{2}{*}{139} & \multirow{2}{*}{-2.16} & \multirow{2}{*}{0.03} \\
\hline & Team & 34 & 2.97 & 0.51 & & & \\
\hline \multirow{2}{*}{ Hostility } & İndividual & 107 & 2.70 & 0.72 & \multirow{2}{*}{139} & \multirow{2}{*}{-2.53} & \multirow{2}{*}{0.01} \\
\hline & Team & 34 & 3.07 & 0.80 & & & \\
\hline
\end{tabular}

Students who participated in the study and engaged in sports; physical aggression $(t=-1.93 ; \mathrm{p}=$ $0.05)$, verbal aggression $(t=-1.98 ; p=0.04)$, indirect aggression $(t=-2.15 ; p=0.03)$, anger $(t=-2,16 ; p=$ $0,03)$, hostility $(t=-2,53 ; p=0,01)$. The arithmetic averages between sub-dimensions were examined to determine which group was in favor of the significant difference. When the values were

examined, physical aggression (individual, $=2.48$; team $3,0=2.93$ ) was sub-dimension, verbal aggression (individual, $=2.79$; team, $9=3.01$ ) in the sub-dimension, indirect aggression (individual $=2$, Sub-dimension of anger (individual $=2,68$; team $=$ 2,97 ) and hostility (individual $=2,70$; team $=3,07$ ) As a result of arithmetic averages, there is a difference in favor of team sports for all dimensions.

Table 5. Comparison of aggression levels according to age of the participants.

'Pearson Correlation on test result

\begin{tabular}{lccc}
\hline & \multicolumn{3}{c}{ Age } \\
\hline Physical Aggression & $\mathrm{n}$ & $\mathrm{r}$ & $\mathrm{p}$ \\
\hline Verbal Agression & 213 & -0.03 & 0.59 \\
\hline Indirect Aggression & 213 & -0.05 & 0.39 \\
\hline Anger & 213 & -0.08 & 0.21 \\
\hline Hostility & 213 & -0.05 & 0.39 \\
\hline
\end{tabular}

Correlation analysis (Pearson Correlation Moment) was performed to investigate the relationship between age variables and Aggressiveness Scale sub-dimensions. According to this, there is no significant relationship between age variable and aggressiveness scale sub-dimensions. 


\section{DISCUSSION \& CONCLUSION}

As a result of this study; It was concluded that males had higher physical aggression than females. In her research, Scharf (20) compared gender and aggression. At the end of the study, verbal aggression did not find any difference between the sexes, but it was found that more men applied to physical aggression. Another researcher, Giles and Heyman (12), investigated the relationship between gender and aggression among adolescents. According to the results, it was concluded that the aggression levels of male individuals were higher than female individuals. In a study by Tiryaki (24), he stated that males are more destructive aggressors than female individuals in the dimension of destructive aggression. The results of the researches are similar to the results of our research. In the study of Yildiz (27) 's level of aggression of sports and non - sports secondary school students, it was concluded that the aggressive and aggressive dimensions of women were higher than the male individuals.

As a result of the findings of the study, it is seen that there is a significant difference when the average of the participants' points taken from the aggressive scale and the department they study. In the sub-dimension of physical aggression, it was found that the average scores of the individuals studying in Physical Education were higher than the ones studying in the Faculty of Education. Since most of the individuals who are engaged in sports have athletes' identity, we can say that they have aggressive behavior due to their ambition to beat their opponents, the tactics given by the trainer and their being under the influence of the viewers. In the study conducted by Yurttaş (28), when we look at the level of aggression among departments, the results are similar to the research we conducted.

As a result of the findings of this study, no significant relationship was found between the sporting status of the participants and the subdimensions of the aggression scale. However, considering the type of sports they do; It was concluded that the students engaged in team sports were more aggressive than the students who were engaged in individual sports. This result can be interpreted by the students who are involved in team sports to express their aggression with mass psychology and to some degree of acceptance of aggression in team sports. Yurttas (28) in the research conducted by the students who engaged in both types of aggression levels were higher than students who do individual sports. By looking at this result, it can be concluded that the level of aggression is lower in individuals who do individual sports.

As a result of the findings of the study, it was concluded that the age variable did not affect the level of aggression. Yurttaş (28), in the study of individuals in different age group from the aggression scale average scores are taken to be a significant difference is observed. The mean scores of individuals between the ages of 21-24 years in the sub-dimensions of physical aggression, anger, hostility and verbal aggression were found to be higher than the mean scores of individuals under 20 years of age. According to the results of Kula (18) 's level of hopelessness levels and aggression of students of industrial vocational high schools, no significant difference was found between gender and age distribution variables and aggression status. In the study conducted by Yurttaş (28), we can interpret the sample group in different age groups but in the research conducted by Kula (18) and the age ranges of the sample groups in this research are close to each other.

\section{REFERENCE}

1. Acet M. Sporda saldırganlık ve şiddet, İstanbul: Morpa Kültür Yayınları Ltd. Şti.2005.

2. Arkonaç SA. Psikoloji zihin süreçleri bilimi. (2. Basım). İstanbul: Alfa Basim Yayım.1998.

3. Balcıŏlu İ. Şiddet ve Toplum. (1. Basım). İstanbul: Bilge Yayıncilık.2001.

4. Buss AH, Perry MP. The aggression questionnaire. Journal of Personality and Social Psychology, 1992: 63, 452-459.

5. Can S. "Aggression questionnare" adlı ölçeğin Türk popülasyonunda geçerlilik ve güvenilirlik çalışması. Yayınlanmamış uzmanlık tezi, Genel Kurmay Başkanlığı Gülhane Askeri Tıp Akademisi Haydarpaşa Eğitim Hastanesi Ruh Sağlığı ve Hastalıkları Servis Şefliği. 2002.

6. Cüceloğlu D. İçimizdeki Çocuk. (1. Basım). Ankara: Remzi Kitabevi.1992.

7. Dervent F. Lise öğrencilerinin saldırganlık düzeyleri ve sportif aktivitelere katılımla ilişkisi. Yayımlanmamış Yüksek Lisans Tezi, Gazi Üniversitesi Eğitim Bilimleri Enstitüsü, Ankara.2007.

8. Dökmen Ü. Yaşama yerleşmek; küçük şeyler 3. (5. Basım). Ankara: Remzi Kitabevi. 2007.

9. Durak N. Son çocukluk dönemi öğrencilerinin saldırganlıklarını belirlemeye yönelik sosyal uyum düzeyinin çeşitli değişkenler açısından incelenmesi. Yayımlanmamış Yüksek Lisans Tezi, Niğde Üniversitesi Sosyal Bilimler Enstitüsü, Niğde.2006. 
10. Erkal M, Güven Ö, Ayan D. Sosyolojik Açıdan Spor. (3. Basım). İstanbul: Der Yayınları.1998.

11. Geçtan E. Psikanaliz ve sonrasi. İstanbul: Remzi Kitabevi.1993.

12. Giles J, Heyman GD. Young Children's Beliefs About The Relationship Between Gender and Aggressive Behavior. Child Development. January/February. 2008: 76,1;107-12.

13. İkizler HC, Karagözoğlu C. Sporda Başarının Psikolojisi. İstanbul: Alfa Basım Yayım Dağıtım.1997.

14. Karasar N. “Bilimsel Araştırma Yöntemleri”. Ankara: Nobel Yayın.2006.

15. Köknel Ö. Kişilik: Kaygıdan Mutluluğa. (13. Basım). İstanbul: Altın Kitaplar Yayınevi.1995.

16. Köknel Ö. Bireysel ve Toplumsal Şiddet. (2. Basım). İstanbul: Altın Kitaplar Yayınevi. 2000.

17. Köksal F. Denetim odağı ile saldırgan davranışlar arasındaki ilişkiler. Yayımlanmamış Doktora Tezi, Atatürk Üniversitesi Sosyal Bilimler Enstitüsü, Erzurum.1991.

18. Kula E. Endüstri Meslek Lisesi Öğrencilerinin Umutsuzluk Düzeyleri ve Saldırganlık Durumları Arasındaki İlişkini İncelenmesi, Yüksek Lisans Tezi, Yeditepe Üniversitesi, Sosyal Bilimler Enstitüsü, Eğitim Yönetimi ve Denetimi Anabilim Dalı, İstanbul. 2008.

19. Pulur A. Sporda şiddet ve saldırganlık. Türkiye Üniversite Sporlar1 Dergisi,2001:1,18.

20. Scharf SC. Gender differences in adolescent aggression: an analysis of instrumentality expressivenes. Doctoral Thesis.
Michigan University Departmant Of Clinical Psychology. Michigan.2000.

21. Solak N. Spor yapan ve yapmayan ortaöğretim öğrencilerinin saldırganlık düzeyleri ile empatik eğilim düzeyleri arasındaki ilişkinin incelenmesi. Çorum ili örneği. Yayımlanmış yüksek lisans tezi, Gazi Üniversitesi, Ankara.2011.

22. Şahin MH. Sporda şiddet ve saldırganlık. Ankara: Nobel Yayın Dağıtım.2003.

23. Tiryaki Ş. Spor Psikolojisi: Kavramlar, Kuramlar ve Uygulama. Ankara:Eylül Kitap ve Yayınevi.2000.

24. Tiryaki Ş. Spor Yapan Bireylerin Saldırganlık Düzeylerinin Belirlenmesi:(Takım ve Bireysel Sporlar Açısından Bir İnceleme). Mersin Üniversitesi, Sağlık Bilimleri Enstitüsü/Beden Eğitimi ve Spor Anabilim Dalı Yüksek Lisans Tezi. Mersin.1996.

25. Var L. Futbol seyircilerinin spor alanlarındaki saldırganlık davranışları hakkında betimsel bir çalışma. Yayımlanmamış Yüksek Lisans Tezi, Gazi Üniversitesi Eğitim Bilimleri Enstitüsü, Ankara.2008.

26. Yetim A. Sosyoloji ve spor. İstanbul: Morpa Kültür Yayınları. 2005.

27. Yıldız S. Spor Yapan ve Spor Yapmayan Ortaöğretim Öğrencilerinin Saldırganlık Düzeylerinin İncelenmesi. Yüksek lisans tezi, Selçuk Üniversitesi, Konya.2009.

28. Yurttaş H. Spor Yapan ve Yapmayan Üniversite Öğrencilerinin Saldırganlık Düzeylerinin İncelenmesi. Yüksek lisans tezi, Atatürk Üniversitesi, Erzurum.2016. 